\title{
Increased glucose carbon recycling in severely insulin deficient Type 1 (insulin-dependent) diabetic subjects
}

\author{
J.J.Benn, R. Rai and P.H.Sönksen \\ United Medical and Dental Schools of Guy's and St. Thomas's, St. Thomas's Hospital, London, UK
}

\begin{abstract}
Summary. Six Type 1 (insulin-dependent) diabetic subjects were studied in order to determine the contribution of recycling of glucose carbon to the overproduction of glucose which is characteristic of the fasting hyperglycaemia produced by insulin withdrawal. The subjects were studied on two occasions, once after an overnight insulin infusion and once following $24 \mathrm{~h}$ of insulin withdrawal. The difference in turnover rates of $1{ }^{14} \mathrm{C}$-glucose and $3{ }^{3} \mathrm{H}$-glucose was used as a measure of glucose recycling. Insulin withdrawal caused a marked metabolic derangement with a rise in non-esterified fatty acids from $0.69 \pm 0.23$ to $1.11 \pm 0.21 \mathrm{mmol} / 1$ (mean \pm SEM, $p<0.05$ ), total ketones from $0.27 \pm 0.06$ to $2.06 \pm 0.51 \mathrm{mmol} / \mathrm{l}(p<0.01)$, cortisol from $341 \pm 43$ to $479 \pm 31 \mathrm{nmol} / \mathrm{l}(p<0.05)$ and growth hormone from $1.1 \pm 0.3$
\end{abstract}

to $19 \pm 5 \mathrm{mu} / \mathrm{l} \quad(p<0.05)$. Glucose turnover rose from $13.8 \pm 2.3 \mu \mathrm{mol} \cdot \mathrm{kg}^{-1} \cdot \mathrm{min}^{-1}$ at a glucose of $6.9 \pm 0.7 \mathrm{mmol} / 1$ in the insulin infused study to $25.8 \pm 4.4 \mu \mathrm{mol} \cdot \mathrm{kg}^{-1} \cdot \mathrm{min}^{-1}$ $(p<0.05)$ at a glucose of $16.4 \pm 0.7 \mathrm{mmol} / 1$ in the insulin withdrawn study. Recycling also rose from $3.0 \pm 0.4 \mu \mathrm{mol}$. $\mathrm{kg}^{-1} \cdot \min ^{-1}$ to $9.4 \pm 2.2 \mu \mathrm{mol} \cdot \mathrm{kg}^{-1} \cdot \mathrm{min}^{-1}(p<0.05)$ when insulin withdrawn, accounting for $23 \pm 3 \%$ and $36 \pm 3 \%$ of glucose turnover, respectively. We conclude that in the severely insulin deficient Type 1 diabetic subject recycling of glucose carbon is a major contributor to the excess glucose production.

Key words: Diabetes mellitus, insulin-dependent, glucose recycling, glucose, insulin, Cori cycle, isotopes.
Fasting plasma glucose levels are maintained by a balance between release and uptake of glucose. Some of the circulating glucose is metabolised to three carbon compounds in the peripheral tissues and then resynthesised to glucose in the liver - an example of 'recycling' of glucose carbon. The best known of these cycles is the Cori cycle which involves formation of lactate in peripheral tissues and its transport to the liver where it is resynthesised to glucose [1]. Various estimates of the contribution of such recycled glucose carbon to fasting endogenous glucose production have been made using isotope tracers, with mean results ranging between 10 and $21 \%$ of total glucose production in most studies of normal man [2-9], with similar results from studies in dogs and rats [10-14] though higher estimates of up to $37 \%$ have been made [15].

The increased fasting plasma glucose concentration characteristic of Type 1 (insulin-dependent) diabetes mellitus is largely due to hepatic overproduction of glucose [16], but the fraction of this glucose production which arises from recycled glucose carbon is not known. Studies in dogs have shown some increase in percentage glucose recycling following pancreatectomy - from 19 to $24 \%$ in one study [10] and from $37 \%$ to $58 \%$ in another [15]. In a study where the transfer of carbon from alanine and lactate to glucose was measured, values for glucose carbon arising from both these sources were $14 \%$ in the normal and $12.5 \%$ in the diabetic dogs [13]. In all these studies absolute values for recycling showed an even greater increase because of the increase in total glucose turnover in the diabetic state. Results obtained in the dog may not accurately reflect changes found in diabetic man, as diabetic dogs tend to show less severe metabolic abnormalities than severely insulin deficient Type 1 diabetic subjects. A recent study in Type 1 diabetic patients showed quite low levels of recycling when infused with insulin ( $7 \%$ at a plasma glucose of $6 \mathrm{mmol} / 1)$, which increased when the subjects were made relatively insulin deficient and hyperglycaemic, to $15 \%$ at a plasma glucose of $15 \mathrm{mmol} / 1$ [17].

The proportion of the hepatic glucose overproduction which arises from recycled glucose carbon in severely insulin deficient Type 1 diabetic patients has not been measured. We have therefore studied patients with Type 1 
diabetes both when insulin withdrawn and when infused with insulin to assess the contribution of recycling to gluconeogenesis, using a dual isotope method.

\section{Subjects and methods}

The study was approved by St. Thomas's Hospital ethical committee and six male Type 1 diabetic patients gave written informed consent to take part in the study. They were aged between 18 and 31 years and with body mass index between 22.9 and $24.1 \mathrm{~kg} / \mathrm{m}^{2}$ - further clinical details are given in Table 1 . They were not taking any medication apart from insulin and had no clinical evidence of retinopathy or neuropathy and a normal plasma creatinine. None were severely insulin resistant (as judged by an insulin dose of less than $1 \mathrm{unit} / \mathrm{kg}$ ) and all showed no C-Peptide response to $1 \mathrm{mg}$ of $\mathrm{i}$.v. glucagon [18].

Each subject was studied on two separate occasions, in random order, at least one week apart. On the day before each study they took a dose of soluble insulin before breakfast but not longer-acting insulin. They had no further insulin until they came to the hospital after an evening meal. For the insulin-withdrawn study, they had no further insulin until after the study whilst, on the other occasion, they were infused with insulin i.v. overnight with a target plasma glucose of $6 \mathrm{mmol} / \mathrm{l}$, and this infusion was continued until the end of the study. No subject became hypoglycaemic during the infusion. On each occasion they were studied in the morning after an overnight fast.

On the morning of the study blood was taken directly into ice cold $10 \%$ perchloric acid for measurement of lactate, pyruvate, acetoacetate and $\beta$-hydroxybutyrate concentrations and immediately frozen and kept at $-70^{\circ} \mathrm{C}$ until assayed. Blood was also taken for measurement of plasma non-esterified fatty acids, growth hormone, cortisol and glucagon concentrations.

The subjects were then given a rapid i. v. bolus of $25 \mu \mathrm{Ci} 1{ }^{14} \mathrm{C}-$ glucose and $75 \mu \mathrm{Ci}$ of $3{ }^{3} \mathrm{H}$-glucose at time $0 \mathrm{~min}$ into an antecutibal vein. The syringe was weighed before and after the injection and an aliquot of injectate taken for liquid scintillation counting before the first weighing, to allow calculation of the injected dose. Blood samples were then taken from a cannula in an antecutibal vein on the contralateral arm at $2,4,6,8,10,15,20,25,30,40,50,60,75,90,100$, $110,120,130,140,150$ mins - placed in fluoride oxalate tubes and the plasma separated after centrifugation at $4{ }^{\circ} \mathrm{C}$. The cannula was kept patent by intermittent flushing with sodium chloride solution $(154 \mathrm{mmol} / \mathrm{l})$; no heparin was used. Urine was collected for the 150 mins of the study, the volume measured and an aliquot assayed for glucose concentration.

\section{Analytical procedures}

Plasma glucose was measured in duplicate using a glucose analyser (Model 23AM, Yellow Springs Instruments, Yellow Springs, Ohio, USA). The aliquot of urine was similarly assayed after dilution. Another aliquot of plasma was used to determine tritiated and carbon 14 glucose activity. The plasma was deproteinised by a variation of the method of Somogyi [19] using sodium hydroxide instead of barium hydroxide. The supernatant was passed through an ion exchange column (AG1-X4, Bio-Rad Laboratories Ltd, Watford, UK) to remove metabolites of glucose, such as lactate. The column eluate was lyophilised to remove tritiated water, reconstituted in $200 \mu \mathrm{l}$ of water and tritium and carbon 14 activities were counted on a liquid scintillation B-counter (Intertechnique SL-400) using 2,5-bis-(5'tert-Butylbenzoxazolyl-[2'])-thiophene (BBOT) as a scintillant. Corrections for quenching and crossover of carbon 14 in the tritium channel were made using a series of standards of variable degree of quenching containing known amounts of $3-{ }^{3} \mathrm{H}$ - or $1-{ }^{14} \mathrm{C}$-glucose. Counting of standards demonstrated a maximum error of $3 \%$ in the correction for ${ }^{14} \mathrm{C}$ in the ${ }^{3} \mathrm{H}$ channel. The effect of this was minimised by using a ${ }^{14} \mathrm{C}$ dose of about one third of the ${ }^{3} \mathrm{H}$ dose. Plasma taken before the injection was used to determine background radioactivity. When known amounts of radioactively labelled glucose were added to plasma and treated in this way the mean recovery was $95 \%$ with a coefficient of variation of $1 \%$. Aliquots of the injectate were added to non-radioactive plasma and run with each assay in order to measure and correct for recovery.

Standard enzymatic spectrophotometric methods were used on neutralised PCA extracts to measure pyruvate, lactate [20], $\beta$-hydroxybutyrate and acetoacetate [21] concentrations. Pyruvate was measured immediately on thawing. Non-esterified fatty acid concentration was measured by a fluorimetric method [22] and insulin, growth hormone, C-Peptide and pancreatic glucagon by $[23,24]$. C-Peptide was measured using an antiserum (GP644) kindly supplied by Dr. Rubenstein (Chicago, Ill, USA).

\section{Calculations}

Glucose metabolic clearance rate (MCR) was calculated from the injected isotope dose and the area under the activity curve (fitted with a two exponential function, and extrapolated to infinity) [25] using the formula:

$\mathrm{MCR}=\frac{\text { Injected dose }}{\text { Area under activity curve }}$

The assumption was made that in the steady state glucose turnover, glucose appearance rate $(\mathrm{Ra})$ and glucose disappearance rate $(\mathrm{Rd})$ were all equal. They were calculated as:

Glucose turnover $=\mathrm{Ra}=\mathrm{Rd}=\mathrm{MCR} \times$ Concentration

The glucose concentration used was the mean of the values for the 150 min of the study. These calculations were made for both carbon 14 glucose and tritiated glucose. As the tritium label in the 3 position cannot recycle back to glucose (it is lost at the triose isomerase step of glycolysis), tritiated glucose turnover was taken to represent total glucose turnover. The carbon 14 label, however, can recycle back into glucose and so recycling is calculated as the difference between glucose turnover measured by the tritiated and carbon 14 labels [2].

Percentage recycling was defined as:

Percentage recycling $=\frac{\text { Recycling }}{\text { Total glucose turnover }} \times 100$

Tissue glucose utilisation rate was defined as total glucose turnover rate minus urinary glucose loss rate.

\section{Statistical analysis}

Unless otherwise stated, results are given as mean \pm SEM. Student's paired $t$-test was used to compare the means for the insulin infused and the insulin withdrawn study. Ketone body concentrations were log transformed [26], as previously suggested [8], to improve the normality of their distribution before analysis by the $t$-test.

\section{Results}

The characteristics of the subjects are shown in Table 1. None were overweight. When the subjects were infused with insulin the mean plasma glucose concentration was $6.9 \pm 0.7 \mathrm{mmol} / 1 \mathrm{compared}$ with $16.4 \pm 0.5 \mathrm{mmol} / 1$ when insulin withdrawn $(p<0.001)$. Plasma glucose concentration did not change significantly over the $150 \mathrm{~min}$ of the study, falling by $0.3 \pm 0.3 \mathrm{mmol} / 1$ in the insulin infused studies and by $0.03 \pm 0.4 \mathrm{mmol} / \mathrm{l}$ in the insulin withdrawn studies. Concentrations of the other metabolites 
Table 1. Clinical data on the subjects

\begin{tabular}{llllll}
\hline Subject & $\begin{array}{l}\text { Age } \\
\text { (years) }\end{array}$ & $\begin{array}{l}\text { Weight } \\
(\mathrm{kg})\end{array}$ & $\begin{array}{l}\mathrm{BMI} \\
\left(\mathrm{kg} / \mathrm{m}^{2}\right)\end{array}$ & $\begin{array}{l}\text { Age at diagnosis } \\
\text { of diabetes } \\
\text { (years) }\end{array}$ & $\begin{array}{l}\text { Dose of } \\
\text { insulin } \\
\text { (U/day) }\end{array}$ \\
\hline 1 & 24 & 68.5 & 22.9 & 3 & 60 \\
2 & 23 & 78.0 & 23.3 & 15 & 80 \\
3 & 31 & 84.4 & 24.1 & 22 & 40 \\
4 & 24 & 68.3 & 23.6 & 12 & 48 \\
5 & 28 & 64.0 & 23.8 & 23 & 24 \\
6 & 19 & 67.0 & 23.5 & 12 & 44 \\
Mean \pm & & & & & $49 \pm 19$ \\
SD & $25 \pm 4$ & $72 \pm 8$ & $23.5 \pm 0.415 \pm 7$ & \\
\hline
\end{tabular}

Table 2. Results of measurements of the concentration of glucose metabolites and hormones involved in control of glucose metabolism in subjects when infused with insulin and when withdrawn from insulin for $24 \mathrm{~h}$

\begin{tabular}{|c|c|c|c|c|}
\hline & $\begin{array}{l}\text { Insulin } \\
\text { infused }\end{array}$ & $\begin{array}{l}\text { Insulin } \\
\text { withdrawn }\end{array}$ & & \\
\hline$\overline{\text { Lactate }(\mathrm{mmol} / \mathrm{l})}$ & $0.77 \pm 0.15$ & $1.07 \pm 0.20$ & $p=0.09$ & $(n=5)$ \\
\hline Pyruvate (mmol/1) & $0.04 \pm 0.01$ & $0.05 \pm 0.01$ & $p=0.27$ & $(n=5)$ \\
\hline Acetoacetate $(\mathrm{mmol} / \mathrm{h})$ & $0.08 \pm 0.01$ & $0.33 \pm 0.06$ & $p<0.02$ & $(n=5)$ \\
\hline $\begin{array}{l}\beta \text {-hydroxybutyrate } \\
(\mathrm{mmol} / \mathrm{l})\end{array}$ & $0.19 \pm 0.04$ & $1.73 \pm 0.46$ & $p<0.01$ & $(n=5)$ \\
\hline Total ketones (mmol/l) & $0.27 \pm 0.06$ & $2.06 \pm 0.51$ & $p<0.01$ & $(n=5)$ \\
\hline $\begin{array}{l}\text { Non-esterified fatty } \\
\text { acids (mmol/1) }\end{array}$ & $0.69 \pm 0.23$ & $1.11 \pm 0.21$ & $p<0.05$ & $(n=6)$ \\
\hline Growth hormone $(\mathrm{mu} / \mathrm{l})$ & $1.1 \pm 0.3$ & $19 \pm 5$ & $p<0.05$ & $(n=6)$ \\
\hline Cortisol (nmol/l) & $341 \pm 43$ & $479 \pm 31$ & $p<0.05$ & $(n=6)$ \\
\hline
\end{tabular}

Table 3. Results of measurements of glucose concentration and glucose turnover in subjects when infused with insulin and when withdrawn from insulin for $24 \mathrm{~h}$

\begin{tabular}{lcll}
\hline & $\begin{array}{l}\text { Insulin } \\
\text { infused }\end{array}$ & $\begin{array}{l}\text { Insulin } \\
\text { withdrawn }\end{array}$ & \\
\hline Plasma glucose $(\mathrm{mmol} / \mathrm{l})$ & $6.9 \pm 0.7$ & $16.4 \pm 0.7$ & $p<0.001$ \\
$\begin{array}{l}\text { Glucose turnover }(=\mathrm{Ra}=\mathrm{Rd}) \\
\left(\mu \mathrm{mol} \cdot \mathrm{kg}^{-1} \cdot \mathrm{min}^{-1}\right)\end{array}$ & $13.8 \pm 2.3$ & $25.8 \pm 4.4$ & $p<0.01$ \\
$\begin{array}{l}\text { Metabolic clearance rate } \\
\left(\mathrm{ml} \cdot \mathrm{kg}^{-1} \cdot \mathrm{min}^{-1}\right)\end{array}$ & $2.0 \pm 0.2$ & $1.5 \pm 0.2$ & $p=0.09$ \\
$\begin{array}{l}\text { Recycling }\left(\mu \mathrm{mol} \cdot \mathrm{kg}^{-1} \cdot \mathrm{min}^{-1}\right) \\
\text { Recycling }(\%)\end{array}$ & $3.0 \pm 0.4$ & $9.4 \pm 2.2$ & $p<0.05$ \\
$\begin{array}{l}\text { Tissue utilisation } \\
\left(\mu \mathrm{mol} \cdot \mathrm{kg}^{-1} \cdot \mathrm{min}^{-1}\right)\end{array}$ & $23 \pm 3$ & $36 \pm 3$ & $p<0.05$ \\
& $13.4 \pm 2.1$ & $19.4 \pm 3.4$ & $p<0.05$ \\
\hline
\end{tabular}

Results are shown as mean $\pm \mathrm{SEM}, n=6$

$\mathrm{Ra}=$ glucose appearance rate $; \mathrm{Rd}=$ glucose dissappearance rate

measured are shown in Table 2 - insulin withdrawal resulting in raised ketones, non-esterified fatty acids, growth hormone and cortisol.

The results of the isotope studies are shown in Table 3. In each study more than $50 \%$ of the isotope had left the circulation by the end of the study period (mean of around $70 \%$ ), allowing reasonably accurate extrapolation of the decay curve to infinity. Glucose appearance rate $(\mathrm{Ra})$, disappearance rate $(\mathrm{Rd})$ and tissue utilisation all increased on withdrawal of insulin. Metabolic clearance rate tended to fall (but not significantly) from $2.0 \pm 0.2 \mathrm{ml} \cdot \mathrm{kg}^{-1}$. $\mathrm{min}^{-1}$ to $1.5 \pm 0.2 \mathrm{ml} \cdot \mathrm{kg}^{-1} \cdot \mathrm{min}^{-1}$ on insulin withdrawal; $p=0.09$. Urinary glucose losses were negligible when insulin infused but made up $6.4 \pm 1.1 \mu \mathrm{mol} \cdot \mathrm{kg}^{-1} \cdot \mathrm{min}^{-1}$, or $25 \%$ of the raised $\mathrm{Rd}$, on insulin withdrawal.

Recycling also rose on insulin withdrawal, both in absolute terms (from $3.0 \pm 0.4$ to $9.7 \pm 2.3 \mu \mathrm{mol} \cdot \mathrm{kg}^{-1}$. $\mathrm{min}^{-1}$ ) and as a percentage of total glucose turnover (from $23 \pm 3 \%$ to $36 \pm 3 \%$ ).

\section{Discussion}

This study examined glucose turnover and recycling in Type 1 diabetic subjects during two states of glycaemic control, using a dual isotope tracer technique. This method gives a measure of recycling of glucose carbon because the difference between the two calculated turnover rates arises from the reincorporation of labelled glucose carbon back into glucose [2]. The use of $3-{ }^{3} \mathrm{H}$-glucose to measure total glucose turnover has previously been discussed and validated [27].

The results show an increased rate of glucose turnover following insulin withdrawal compared with a group of normal subjects studied in our laboratory, using a bolus injection of $3{ }^{3} \mathrm{H}$-glucose $\left(10.7 \pm 1.7 \mu \mathrm{mol} \cdot \mathrm{kg}^{-1}\right.$. $\min ^{-1}$, mean $\pm \mathrm{SD}$ ) [16]. The raised glucose turnover rate confirms that hyperglycaemia in the insulin deficient state is a result of an increase in glucose production rate, as has previously been demonstrated in both Type 1 [16] and Type 2 (non-insulin-dependent) [28] diabetic subjects. The increased tissue utilisation has also previously been demonstrated in insulin deficient Type 1 diabetic patients [16] and is probably the result of the mass action effect of glucose, which in normal subjects is known to cause an increase in glucose uptake in the absence of changes in insulin concentration in normal $[29,30]$ and in Type 1 diabetic subjects [31]. The source of carbon for the increased glucose production is uncertain. An increase in transfer of carbon from lactate and alanine to glucose, in absolute but not in percentage terms, has been found in dogs [13], though even in this study a large part of the increase could not be accounted for by these compounds. We have demonstrated that a significant part of this increased glucose appearance rate in profoundly insulin deficient man is accounted for by an increase in recycling of glucose carbon (both in absolute terms and as a percentage of glucose appearance rate). This increased recycling presumably results from increased conversion of glucose to three carbon compounds and their uptake and re-conversion to glucose in the liver, however studies of the turnover rates of these three carbon compounds would be required to elucidate this further.

Measurements of glucose recycling are dependent on the method used, though there is general agreement between the two commonly used isotope methods [2]. A problem common to both methods is exchange of ${ }^{12} \mathrm{C}$ and ${ }^{14} \mathrm{C}$ in the oxaloacetate pool, a pool shared by the Krebs cycle and the gluconeogenic pathways, which leads to an underestimation of recycling, by a factor dependent on the flux through the oxaloacetate pool [32]. Thus true recycling may be even higher than the estimates made in this 
study. Errors in the estimation of recycling could also occur if glucose molecules labelled with the two isotopes are metabolised differently in the body. It has been shown that the effects of hyperglycaemia on glucose turnover measured with $3{ }^{3} \mathrm{H}$ glucose parallel those measured by 6 ${ }^{14} \mathrm{C}$ glucose corrected for recycling, though values obtained with $3{ }^{3} \mathrm{H}$ were marginally lower - raising the possibility of an isotope effect of the tritium (as has been suggested in animals [33, 34] and during euglycaemic clamp studies in man [35]). This would again result in an underestimate of recycling.

Previous studies have in general found lower rates of recycling than those reported here in poorly controlled diabetes, both in dogs and in man. This discrepancy probably arises because of differences in the severity of the metabolic derangement. The subjects in this study were severely insulin deficient due to insulin withdrawal, in the absence of any endogenous insulin secretion, and not merely hyperglycaemic. Their metabolic state was characterised by elevated ketone, non-esterified fatty acids, growth hormone and cortisol levels together with hyperglycaemia. The presence of even a small amount of insulin (as for instance in the study of Darmaun et al. [17]) may be sufficient to inhibit gluconeogenesis and glucose recycling - suggesting that hypoinsulinaemia is a more important factor than hyperglycaemia in increasing glucose recycling.

Another factor which may contribute to the discrepancy in the magnitude of recycling is the difference in methodology (bolus compared to infusion experiments). Sources of error when using a tracer infusion have been highlighted recently in studies in Type 2 diabetes [36], which suggest that infusion experiments with equilibration times of the order of 2-3 h may not accurately measure glucose turnover in the presence of a high fasting plasma glucose concentration, because of failure to reach a steady state and that the choice of priming dose is critical in this type of experiment. The problem may be even greater when a steady state is necessary in the recycled glucose (essential for a steady state of carbon 14 glucose). This would suggest that infusion experiments are not ideal for these studies, though some workers have taken great care in trying to minimise the errors involved [17].

In conclusion, recycling of glucose carbon makes up a major part of the raised glucose production and consequent hyperglycaemia in the fasting, insulin deficient Type 1 diabetic subject.

Acknowledgements. We would like to thank Miss L. Beckwith and Miss S. Bowes for their expert help in carrying out these studies.

\section{References}

1. Cori CF (1931) Mammalian carbohydrate metabolism. Physiol Rev 11: 143-275

2. Streja DA, Steiner G, Marliss EB, Vranic M (1977) Turnover and recycling of glucose in man during prolonged fasting. Metabolism 26: 1089-1098

3. Bell PM, Firth RG, Rizza RA (1986) Effects of hyperglycaemia on glucose production and utilisation in humans. Measurement with $\left[2^{3} \mathrm{H}\right]-,\left[3^{3} \mathrm{H}\right]-$, and $\left[6^{14} \mathrm{C}\right]$ Glucose. Diabetes $35: 642-648$
4. Tserng K-Y, Kalhan SC (1983) Estimation of glucose carbon recycling and glucose turnover with $\left[\mathrm{U}-{ }^{13} \mathrm{C}\right]$ glucose. Am J Physiol 245: E476-E482

5. Kreisberg RA, Siegal AM, Crawford Owen W (1971) Glucoselactate interrelationships: effect of ethanol. J Clin Invest 50: 175185

6. Reichard GA Jr, Moury NF Jr, Hochella NJ, Patterson AL, Weinhouse S (1963) Quantitative estimation of the Cori cycle in the human. J Biol Chem 238: 495-501

7. Waterhouse C, Keilson J (1969) Cori cycle activity in man. J Clin Invest 48: 2359-2366

8. Nosadini R, Noy GA, Nattrass M, Alberti KGMM, Johnston DG, Home PD, Ørskov H (1982) The metabolic and hormonal response to acute normoglycaemia in Type 1 (insulin-dependent) diabetes: studies with a glucose controlled insulin infusion system (artificial endocrine pancreas). Diabetologia 23: 220-228

9. DeFronzo RA, Jacot E, Jequier E, Maeder E, Wahren J, Felber JP (1981) The effect of insulin on the disposal of intravenous glucose. Results from indirect calorimetry and hepatic and femoral venous catheterisation. Diabetes 30: 1000-1007

10. Stevenson RW, Parsons JA, Alberti KGMM (1983) Effect of intraportal and peripheral insulin on glucose turnover and recycling in diabetic dogs. Am J Physiol 244: E190-E195

11. Dunn A, Chenoweth M, Schacfer LD (1967) Estimation of glucose turnover and the Cori cycle using glucose- $6-\mathrm{t}^{14} \mathrm{C}$. Biochemistry 6: 6-11

12. Freminet A, Poyart C (1975) Lactate-glucose interrelationships, glucose recycling and the Cori cycle in normal fed rats. Pflugers Arch 361:25-31

13. Hetenyi G Jr, Layberry RA, Foster DM, Berman M (1980) Transfer of carbon atoms among circulating glucose, alanine, and lactate in pancreatectomized dogs. Am J Physiol 239: E39-E44

14. Issekutz B (1977) Studies on hepatic glucose cycles in normal and methylprednisolone-treated dogs. Metabolism 26: 157-170

15. Freyse EJ, Fischer U, Albrecht G (1983) Glucose metabolism studied isotopically in diabetic dogs: effect of restoration of peripheral normoinsulinaemia by the artificial B cell. Diabetologia 25: $411-417$

16. Hall SEH, Saunders J, Sönksen PH (1979) Glucose and free fatty acid turnover in normal subjects and in diabetic patients before and after insulin treatment. Diabetologia 16:297-306

17. Darmaun D, Cirillo D, Koziet J, Chauvet D, Young VR, Robert J-J (1988) Whole body glucose kinetics in Type I diabetes studied with $\left[6,6-^{2} \mathrm{H}\right]$ and $\left[\mathrm{U}-{ }^{13} \mathrm{C}\right]$-glucose and the artificial $\mathrm{B}$-cell. Metabolism 37: 491-498

18. Faber OK, Binder C (1977) C-Peptide response to glucagon. A test for residual - cell function. Diabetes 26: 605-610

19. Somogyi M (1945) Determination of blood sugar. J Biol Chem 160: 69-73

20. Hohorst HJ, Kreutz FH, Bucher TL (1959) Über Metabolitgehalte und Metabolitkonzentrationen in der Leber der Ratte. Biochemische Zeitschrift 332: 18-46

21. Williamson DH, Mellanby J, Krebs HA (1962) Enzymatic determination of D(-)b-hydroxybutyrate and acetoacetate in blood. Biochem J 82: 90-96

22. Carruthers ME, Young DAB (1973) Free fatty acid estimation by a semi-automated fluorimetric method. Clin Chim Acta 49: 341-348

23. Sonksen PH (1976) Double antibody technique for the simultaneous assay of insulin and growth hormone. In: Antoniades HN (Ed) Hormones in human blood: detection and assay. Harvard University Press

24. Ghatei MA, Uttenthal LO, Christofides ND, Bryant MG, Bloom SR (1983) Molecular forms of human enteroglucagon in tissue and plasma: plasma responses to nutrient stimuli in health and in disorders of the upper gastrointestinal tract. J Clin Endocrinol Metab 57: 488-495

25. Hetenyi G Jr, Norwich KH (1974) Validity of the rates of production and utilisation of metabolites as determined by tracer methods in intact animals. Federation Proc 33: 1841-1848 
26. Armitage $P$ (1977) Statistical methods in medical research. Blackwell, Oxford London Edinburgh Melbourne

27. Altszuler N, Barkai A, Bjerknes C, Gottlieb B, Steele R (1975) Glucose turnover values in the dog obtained with various species of labelled glucose. Am J Physiol 229: 1662-1667

28. Firth RG, Bell PM, Marsh HM, Hansen I, Rizza RA (1986) Postprandial hyperglycaemia in patients with noninsulin-dependent diabetes mellitus. Role of hepatic and extrahepatic tissues. J Clin Invest 77: 1525-1532

29. Best JD, Taborsky GJ, Halter JB, Porte D (1981) Glucose disposal is not proportional to plasma glucose level in man. Diabetes $30: 847-850$

30. Gottesman I, Mandarino L, Gerich J (1983) Estimation and kinetic analysis of insulin-independent glucose uptake in human subjects. Am J Physiol 244: E632-E635

31. Hansen IL, Cryer PE, Rizza RA (1985) Comparison of insulinmediated and glucose-mediated glucose disposal in patients with insulin-dependent diabetes mellitus and in non-diabetic subjects. Diabetes 34: 751-755

32. Hetenyi G $\operatorname{Jr}$ (1982) Correction for the metabolic exchange of ${ }^{14} \mathrm{C}$ for ${ }^{12} \mathrm{C}$ atoms in the pathway of gluconeogenesis in vivo. Fed Proc 41: 104-109
33. Rieder S, Rose I (1959) The mechanism of the triosephosphate isomerase reaction. J Biol Chem 234: 1007-1010

34. Rose I, Kellermeyer R, Stjernholm R, Wood H (1962) The distribution of ${ }^{14} \mathrm{C}$ in glycogen from deuterated glycerol $-{ }^{14} \mathrm{C}$ as a measure of the effectiveness of triosephosphate isomerase in vivo. J Biol Chem 237:3325-3331

35. Argoud GM, Schade DS, Eaton RP (1987) Underestimation of hepatic glucose production by radioactive and stable tracers. Am J Physiol 252: E606-E615

36. Glauber H, Wallace P, Brechtel G (1987) Effect of fasting on plasma glucose and prolonged tracer measurement of hepatic glucose output in NIDDM. Diabetes 36: 1187-1194

Received: 29 June 1989

and in revised form: 2 October 1989

Dr. J.J.Benn

Department of Medicine

St. Thomas's Hospital

Lambeth Palace Rd.

London SE1 7EH

UK 